GLOBAL JOURNAL OF PURE AND APPLIED SCIENCES VOL. 24, 2018: 61-67

COPYRIGHTৎ BACHUDO SCIENCE CO. LTD PRINTED IN NIGERIA ISSN 1118-0579

www.globaljournalseries.com, Email: info@globaljournalseries.com

\title{
EQUILIBRIUM AND KINETICS OF COLOUR ADSORPTION FROM TEXTILE WASTEWATER BY A NOVEL ADSORBENT
}

\author{
G. D. AKPEN, M. I. AHO AND M. H. MAMWAN \\ (Received 23 February 2018; Revision Accepted 3 April 2018)
}

\begin{abstract}
Activated carbons were produced from a local variety of mango seed by carbonizing the inner seed before activation with $\mathrm{ZnCl}_{2}$ using an impregnation ratio of 1:4. Laboratory batch studies were conducted in order to generate data for kinetic and equilibrium modelling of adsorption of colour by the produced mango seed endocarp activated carbon (MSEAC) for the purpose of determining the mechanism and rate controlling steps of the adsorption process. Langmuir, Freundlich and Tempkin Isotherms were adopted. While the kinetic models used were pseudo first order kinetic, pseudo second order kinetic, Intra-particle diffusion and Elovich models. The pseudo second order model gave the highest coefficient of determination $\left(R^{2}\right)$ of 0.999 (indicating goodness of fit) compared to other kinetic models tested. This suggests that chemisorption is the rate-limiting step in this biosorption system. Langmuir isotherm fitted experimental data better compared with the other tested models $\left(R^{2}=0.9987\right)$, implying that the adsorption process is based on a monolayer adsorption. Chi-squared test performed on all the models confirmed the goodness of fit of the generated data to the Langmuir and pseudo-second order over the other isotherm and kinetic models because they had the least caculated Chi- squared $\left(x^{2}\right.$ Cal $)$ values of 5.2 and 3.2 respectively. It was recommended that these two models are reliable tools for predicting the mechanism and rate of adsorption of colour from textile wastewater by the produced MSEAC.
\end{abstract}

KEYWORDS: Mango seed endocarp, activated carbon, colour, kinetics, isotherms, Textile wastewater.

\section{INTRODUCTION}

Activated carbon has been used worldwide as an effective adsorbent for removing colour and chemical contaminants from water and waste water. Currently, Nigeria imports commercial carbon at high cost for water treatment which puts significant burden on the water treatment budget. A review of literature revealed many attempts on the use of agricultural wastes/by-products as adsorbents for water/wastewater treatment. The adsorption of phosphate by Terminalia catappa based activated carbon was studied by Ochonogor et al. (1999). Activated carbon was produced from Rosa canina and applied in the removal of dye from wastewater (Gurses et al., 1999). Rice husk and corncobs based activated carbon was produced and characterized by Aloko and Adebayo (2007) and used to remove phosphates from water. Jatropha husk activated carbon was used by Namasivayam et al. (2007) for the removal of anions, heavy metals, organics and dyes from water. High removal efficiencies were achieved by mango seed shell activated carbon in the removal of colour and phenol from wastewater (Akpen et al. 2011, 2014].

However, scanty information is available on the use of mango seed endorcarp as adsorbent, though the potential for its use has been recognised by some researchers (Elizalde-Gonzalez \& Hernandez-Montoya, 2007, Kwagher and Adejoh, 2012). In Nigeria, mango seed litter around streets especially in the suburban areas and they constitute environmental nuisance. The utilization of these seeds for wastewater treatment will have cost saving and waste management advantages. The aim of this study is to investigate the mechanism and nature of adsorption of colour from wastewater by mango seed activated carbon. The preparation, characterization and the optimum conditions for the removal of colour by MSEAC are reported elsewhere (Akpen et al., 2017).

\section{MATERIALS AND METHODS}

Production of Mango Seed Endocarp Activated
Carbon (MSEAC)
Mango seeds were collected from Mangar District of
Bokkos Local Government Area of Plateau State,
Nigeria, air-dried and broken to expose the endocarp
which was further air dried. The air dried mango seed
endocarps were carbonized in a muffle furnace at a
temperature of $500^{\circ} \mathrm{C}$ for 2 hours and allowed to cool for
3 hours before activation with $\mathrm{ZnCl}_{2}$ solution. The $\mathrm{ZnCl}_{2}$
solution was prepared by dissolving $100 \mathrm{~g}$ of anhydrous
$\mathrm{ZnCl}_{2}$ in $100 \mathrm{~mL}$ of distilled water. $400 \mathrm{~g}$ of the

G. D. Akpen, Civil Engineering Department, University of Agriculture, Makurdi, Nigeria.

M. I. Aho, Civil Engineering Department, University of Agriculture, Makurdi, Nigeria.

M. H. Mamwan, Civil Engineering Department, University of Agriculture, Makurdi, Nigeria.

(C) 2018 Bachudo Science Co. Ltd. This work is licensed under Creative Commons Attribution 4.0 International license. 
carbonized material were mixed with the prepared $\mathrm{ZnCl}_{2}$ solution to obtain an impregnation ratio of $1: 4$. That is 1 part of $\mathrm{ZnCl}_{2}$ to 4 parts of carbonized mango seed endocarp by mass.

\section{Adsorption studies}

Batch kinetic studies were carried out by adding a fixed amount of MSEAC of $0.8 \mathrm{~g}$ (size $150 \mu \mathrm{m}-850 \mu \mathrm{m})$ into $500 \mathrm{~mL}$ flasks containing $100 \mathrm{~mL}$ of textile wastewater obtained from Angel Spinning Textile Industry, Kano. The flasks were agitated in a flocculator at $90 \mathrm{rpm}$ at room temperature $\left( \pm 34^{\circ} \mathrm{C}\right)$ at preset time intervals of 10 $\mathrm{min}, 20 \mathrm{~min}, 30 \mathrm{~min}, 40 \mathrm{~min}, 50 \mathrm{~min}, 60 \mathrm{~min}$ and $70 \mathrm{~min}$ respectively. The initial concentration of colour, $\mathrm{pH}$, and carbon dose adopted were respectively $512 \mathrm{Pt}-\mathrm{Co}$ units, 7.6 and $0.8 \mathrm{~g}$. Colour concentrations were measured by a DR 2000 UV spectrophotometer $(\mathrm{HACH}$ Company, USA) according to the standard method specified in the manual. The amount of colour adsorption per unit mass of adsorbent, $\mathrm{q}_{\mathrm{t}}(\mathrm{Pt}-\mathrm{Co} / \mathrm{g})$ was calculated according to Equation (1):

$q_{t}=\frac{\left(c_{0}-c_{t}\right)}{w} V$

where $\mathrm{C}_{0}$ and $\mathrm{C}_{\mathrm{t}}$ (Pt-Co) are the liquid-phase concentrations of colour at initial and at preset time, $t$ respectively. $V(L)$ is the volume of the solution and $W$ $(\mathrm{g})$ is the mass of dry adsorbent used.

The procedures of equilibrium experiments were basically identical to those of kinetic tests except that different initial concentrations of $215,302,399,427$, 450, 512 and $550 \mathrm{Pt}-\mathrm{Co}$ units of the coloured textile wastewater of $\mathrm{pH} 7.6$ were adopted. The time to reach equilibrium adopted was 40 minutes. The amount of equilibrium adsorption, $\mathrm{q}_{\mathrm{e}}$ (Pt-Co /g), was calculated using Equation (2):

$q_{e}=\frac{\left(c_{o}-c_{e}\right)}{w} V$

where $\mathrm{C}_{\mathrm{e}}$ (Pt-Co) is the liquid-phase concentration of colour at equilibrium.

\section{Adsorption Isotherm Modelling}

The equilibrium adsorption isotherm is one of the most important approach to understand the mechanism of adsorption systems. The Langmuir (1918), Freundlich (1906) and Temkin (Temkin and Pyzhev, 1940) isotherm equations were used to interpret the experimental data. Langmuir isotherm theory is based on the assumption that adsorption is on a homogeneous surface, i.e., the surface consists of identical sites, equally available for adsorption and with equal energies of adsorption, and that the adsorbent is saturated after one layer of adsorbate molecules forms onto the surface The linearized form of the Langmuir adsorption isotherm equation is expressed as in Equation (3):

$$
\frac{\mathrm{c}}{\mathrm{q}}=\frac{\mathrm{c}}{\mathrm{q}_{\mathrm{n}}}+\frac{1}{\mathrm{~K}_{\mathrm{a}} \mathrm{q}_{\mathrm{n}}} \text {. }
$$

where, $\mathrm{q}=$ mass of solute adsorbed/mass of adsorbent; $\mathrm{q}_{\mathrm{n}}=$ mass of solute adsorbed/mass of adsorbent for $\mathrm{a}$ complete monolayer, $\mathrm{c}=$ concentration of solutes in solution; and $\mathrm{K}_{\mathrm{a}}=$ constant related to enthalpy of adsorption (Langmuir (1918). The Langmuir constants; are obtained by plotting $\mathrm{c} / \mathrm{q}$ against $\mathrm{c}$. The slope, $\mathrm{a}=1 /$ $q_{n}$ and intercept, $b=1 / K_{a} q_{n}$.

The Freundlich isotherm equation is an empirical expression that encompasses the heterogeneity of the surface and the exponential distribution of sites and their energies and is expressed as:

$q=K_{f} C^{\frac{1}{n}}$

In linearized form, Equation (4) is given by Equation (5) thus:

$\operatorname{In} \mathrm{q}=\operatorname{In} K_{\mathrm{f}}+\frac{1}{\mathrm{n}} \operatorname{In} \mathrm{C}$.

where, $\mathrm{C}$ is the equilibrium concentration of the solute $(\mathrm{mg} / \mathrm{L})$ and $\mathrm{q}$ is the equilibrium

adsorption capacity $(\mathrm{mg} / \mathrm{g}) . \mathrm{K}_{\mathrm{F}}$ and $1 / \mathrm{n}$ are constants representing the adsorption capacity and the intensity of the adsorption respectively and can be calculated from the linear plot of $\ln q$ versus $\ln C$. The slope $(1 / n)$ measures the surface heterogeneity. Heterogeneity becomes more prevalent as $1 / n$ gets closer to zero (Valix et al., 2004).

The Temkin isotherm equation assumes that the heat of adsorption of all the molecules in the layer decreases linearly with coverage due to adsorbent-adsorbate interactions, and that the adsorption is characterized by a uniform distribution of the binding energies, up to some maximum binding energy. The linearized Temkin isotherm is given in Equation (6):

$q=B \ln K_{T}+B \ln C$.

where, $\mathrm{B}=\mathrm{RT} / \mathrm{b} . \mathrm{K}_{\mathrm{T}}$ is the equilibrium binding constant (L/mg) corresponding to the maximum binding energy and $b$ is a constant related to the heat of adsorption. $R$ is the gas constant $(8.314 \mathrm{~J} / \mathrm{mol} \mathrm{K})$ and $\mathrm{T}$ is the absolute temperature $(\mathrm{K})$. A plot of $q$ versus $\mathrm{In} C$ enables the determination of the isotherm constants $\mathrm{K}_{\mathrm{T}}$ and $\mathrm{b}$ from the intercept and slope respectively.

\section{Adsorption Kinetics Modelling}

The kinetics of adsorption data was processed to understand the dynamics of adsorption process in terms of the order of rate constant. The rate constants of chemical adsorption of colour from the textile wastewater were determined using the pseudo-first order, pseudo-second order, Elovich (Chien and Clayton, 1998), and the intra-particle diffusion (Weber and Morris, 1963) models.

The pseudo-first-order rate expression based on solid capacity is generally expressed as follows (Lagergren, 1898):

$\frac{\mathrm{dq}_{\mathrm{t}}}{\mathrm{dt}}=\mathrm{K}_{1}\left(\mathrm{q}_{\mathrm{e}}-\mathrm{q}_{\mathrm{t}}\right)$ 
where, $\frac{d q_{t}}{d t}$ is the rate of adsorption, $q_{e}$ is the amount of adsorbate adsorbed at equilibrium (mg/g), $q_{t}$ is the amount adsorbed at any time $\mathrm{t}(\mathrm{mg} / \mathrm{g}), \mathrm{k}_{1}$ is the rate constant of first order adsorption (I/minutes). After integration and applying boundary conditions, $\mathrm{t}=0$ to $\mathrm{t}$ and $\mathrm{q}_{\mathrm{t}}=0$ to $\mathrm{q}_{\mathrm{t}}$; Equation (7) becomes:

$\log \left(\mathrm{q}_{\mathrm{e}}-\mathrm{q}_{\mathrm{t}}\right)=\log \left(\mathrm{q}_{\mathrm{e}}\right)-\frac{\mathrm{k}_{1}}{2.303} \mathrm{t}$

Values of adsorption rate constant $\left(k_{1}\right)$ for the adsorbate are determined from the straight line plot of $\log \left(q_{e}-q_{t}\right)$ against $t$. A high value of the coefficient of determination is an indication that the rate of removal of the adsorbate by the adsorbent follows the pseudo-first-order equation.

The pseudo-second-order equation is also based on the sorption capacity of the solid phase. It predicts the behaviour over the whole range of data. Furthermore, it is in agreement with chemisorption being the rate controlling step and is expressed as (Ho et al., 2000):

$\frac{d q_{t}}{d t}=k_{2}\left(q_{e}-q_{t}\right)^{2}$

where, $k_{2}$ is the rate constant of second orderadsorption (g/mg.min). $\frac{d q_{t}}{d t}, q_{t}, q_{e}$ and $t$ are as defined earlier. For the same boundary conditions as in Pseudofirst order model, the integrated form of Equation (9) becomes:

$\frac{1}{u_{e}-y_{t}}=\frac{1}{y_{e}}+k_{2} t$

Equation (10) can be rearranged to obtain:

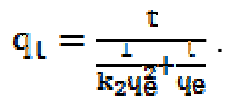

Equation (11) can be rearranged to obtain a linear form:

$\frac{t}{q_{t}}=\frac{1}{k_{2} q_{e}^{2}}+\frac{1}{q_{e}} t$

If the initial sorption rate, $\mathrm{h}(\mathrm{mg} / \mathrm{g}$. minutes) at $\mathrm{t}=0$ is defined as:

$\mathrm{h}=\mathrm{k}_{2} \mathrm{q}_{\mathrm{e}}{ }^{2}$.

Then replacing $k_{2}, \mathrm{qe}_{e}^{2}$ in Equation (12) with $\mathrm{h}$, we obtain:

$\frac{\mathrm{t}}{\mathrm{q}_{\mathrm{t}}}=\frac{1}{\mathrm{~h}}+\frac{1}{\mathrm{~g}_{\mathrm{e}}} \mathrm{t}$

Equation (14) does not have the disadvantage of the problem with assigning an effective $\mathrm{q}_{\mathrm{e}}$. If pseudo-second order kinetics is applicable, the plot of $t / q_{t}$ against $t$ of Equation (14) should give a linear relationship from which $q_{e}$ and $h$ values will be determined from the slope and intercept of the plot respectively and there is no need to know any parameter beforehand (Ho and McKay, 1998). $\mathrm{k}_{2}$ is then determined from Equation (13).
The Elovich model is mainly applicable for chemisorption kinetics. The equation is often valid for systems in which the adsorbing surface is heterogeneous (Sivakumar and Palanisamy, 2009). The Elovich model is generally expressed as:

$\frac{d q_{t}}{a t}=\alpha e^{-\beta q_{t}}$.

To simplify the Elovich equation, Chien and Clayton (1998) assumed that $\alpha \beta t>>1$ and integrating Equation (15) for the boundary conditions, $q t=0$ at $t=0$ and $q_{t}=$ $\mathrm{q}_{\mathrm{t}}$ at $\mathrm{t}=\mathrm{t}$ yields in linear form:

$\mathrm{q}_{\mathrm{t}}=\frac{1}{\beta} \ln (\alpha \beta){ }_{\mathrm{f}}^{1} \ln \mathrm{t}^{\prime}$

where, $\alpha$ is the initial adsorption rate ( $\mathrm{mg} / \mathrm{g}$ minutes) and $\beta$ is the desorption constant and is related to the extent of surface coverage and the activation energy for chemisorptions $(\mathrm{g} / \mathrm{mg}) . \mathrm{q}_{\mathrm{t}}, \mathrm{q}_{\mathrm{e}}$ and $\mathrm{t}$ are as defined under Equation (7). A plot of $\mathrm{q}_{\mathrm{t}}$ against $\ln \mathrm{t}$ gives a linear trend with a slope of $(1 / \beta)$ and an intercept of $1 / \beta \ln (\alpha \beta)$.

The most commonly used technique for identifying the mechanism involved in the adsorption process is by using intra-particle diffusion model as proposed by (Weber and Morris, 1963) thus:

$q_{t}=k_{d} t^{1 / 2} \mid I$.

where, $K_{d}$ is the intra-particle diffusion rate constant. $q_{t}$ and $t$ are as defined under Equation (7). If intra-particle diffusion occurs, then a plot of $q_{t}$ against $t^{1 / 2}$ will be linear and the line will pass through the origin if intra-particle diffusion was the only rate limiting parameter controlling the process. Otherwise, some other mechanism such as external mass transfer is also involved. Values of I give an idea about the thickness of the boundary layer.

\section{Model Verification}

To test the reliability of the developed models for prediction of the adsorption process, a chi-squared $\left(\mathbf{x}^{2}\right)$ test was performed according to Equation (18) thus:

$\chi^{2}=\sum_{i=1}^{N} \underset{e_{i}}{\left(0_{i}-e_{i}\right)^{2}}=\sum\left|\begin{array}{c}\text { (Observed-Expected })^{2} \\ \text { Expected }\end{array}\right|$.

where, $\mathrm{N}=$ independent observations in the sample and $\mathrm{k}=1$ is the population parameter. $\mathrm{N}=7$ for both the kinetic and equilibrium data. The results of the chisquared test are presented in Table 4.

\section{RESULTS AND DISCUSSIONS}

\section{Characteristics of Textile Wastewater}

The results from the characterization of Textile waste water are presented in Table 1. The concentrations of BOD and COD were higher than values specified by National Environmental Standards Regulation and Enforcement Agency (NESREA). Other parameters analysed were within acceptable limits specified by NESREA except, the five-day dissolved oxygen concentration. 
Table 1: Characteristics of Textile Wastewater

\begin{tabular}{|l|l|l|}
\hline Wastewater parameter & Value & NESREA standards \\
\hline $\mathrm{pH}$ & 7.6 & $6-9$ \\
\hline Colour [Pt-Co units $\equiv \mathrm{mg} / \mathrm{L}]$ & 512 & 25 \\
\hline Chloride [mg/L] & 134.6 & 600 \\
\hline Total dissolved solid, TDS [mg/L] & 176.8 & $500-1500$ \\
\hline Suspended solid, SS [mg/L] & 314 & 30 \\
\hline Total Solid, TS [mg/L] & 490.8 & 2000 \\
\hline Dissolved oxygen - initial [mg/L] & 5.0 & 4.0 \\
\hline Dissolved oxygen - 5 day [mg/L] & 1.4 & Not $<2$ \\
\hline BOD [mg/L] & 214 & 20 \\
\hline COD [mg/L] & 428 & 80 \\
\hline Total coliform [MPN/100 mL of $\left.\mathrm{H}_{2} \mathrm{O}\right]$ & 550 & 400 \\
\hline
\end{tabular}

\section{Adsorption Isotherms Results}

The equilibrium adsorption isotherm is one of the most important data to understand the mechanism of adsorption systems. Values of all the isotherm constants as obtained are shown in Table 2 along with the values of the coefficient of determination $\left(R^{2}\right)$. The Langmuir model fitted the experimental data better than the other isotherm models given the higher values of $\mathrm{R}^{2}$ obtained. Conformation of the experimental data to the Langmuir isotherm indicates the formation of a monolayer of colour molecules at the outer surface of the mango seed endocarp activated carbon. It further implies that, the adsorbed molecules cannot migrate across the surface or interact with neighbouring molecules (an indication of chemisorption). Similar observations were reported by Bello et al. (2010) on the adsorption of acid orange 10 dye onto treated sawdust and Namasivayam and Kavitha (2002)] on the adsorption of Congo red dye on treated sawdust from coir pith.

\section{Adsorption Kinetics Results}

The intra-particle diffusion plot presented in Fig.1 indicates that the linear plot for a wide range of contact times did not pass through the origin. This deviation from the origin may be due to the variation of mass transfer in the initial and final stages of adsorption as reported by (Sivakumar and Palanisamy, 2009). This indicates that although intra-particle diffusion was involved in the adsorption process, it was not the sole rate-controlling step. This also confirms that adsorption of colour on the adsorbent was a multi-step process, involving adsorption on the external surface and diffusion into the interior. The kinetic parameters for the adsorption of colour from the textile wastewater were calculated as presented in Table 3 . The coefficient of determination $\left(R^{2}\right)$ for the pseudo-second-order kinetic model was higher than the other kinetic models tested implying that the adsorption system studied obeys the pseudo second-order kinetic model. This suggests that the rate-limiting step in these biosorption systems may be chemisorptions involving valence forces through sharing or exchange of electrons between adsorbent and the adsorbate as reported by (Ho and McKay, 1999).

Table 2: Isotherm parameters for the removal of colour by MSEAC.

\begin{tabular}{|l|l|l|}
\hline Equilibrium isotherm & $\begin{array}{l}\text { Equilibrium } \\
\text { constants/parameters }\end{array}$ & Goodness of fit $\left(\mathrm{R}^{2}\right)$ \\
\hline $\begin{array}{l}\text { Langmuir isotherm } \\
\mathrm{c} / \mathrm{q}=\mathrm{c} / \mathrm{q}_{\mathrm{n}}+\mathrm{k}_{\mathrm{a}} / \mathrm{q}_{\mathrm{n}}\end{array}$ & $\begin{array}{l}\mathrm{q}_{\mathrm{n}}=588.23[\mathrm{Pt}-\mathrm{Co} / \mathrm{g}] \\
\mathrm{Ka}=8.5 \times 10^{-7}\left[{\left.\mathrm{Pt}-\mathrm{Co}^{-1}\right]}^{-}\right]\end{array}$ & 0.998 \\
\hline $\begin{array}{l}\text { Freundlich isotherm } \\
\text { Inq }=\text { Ink } \mathrm{f}+1 / \mathrm{n} \text { Inc }\end{array}$ & $\begin{array}{l}\mathrm{n}=10.08 \\
\mathrm{~K}_{\mathrm{f}}=386.75\end{array}$ & 0.4994 \\
\hline $\begin{array}{l}\text { Temkin isotherm } \\
\mathrm{q}=\mathrm{B} \ln \mathrm{A}+\mathrm{BInC}\end{array}$ & $\mathrm{A}=10.54[\mathrm{~kJ}]$ & 0.5698 \\
$\mathrm{~B}=43.09[\mathrm{~J}]$ & \\
\hline
\end{tabular}




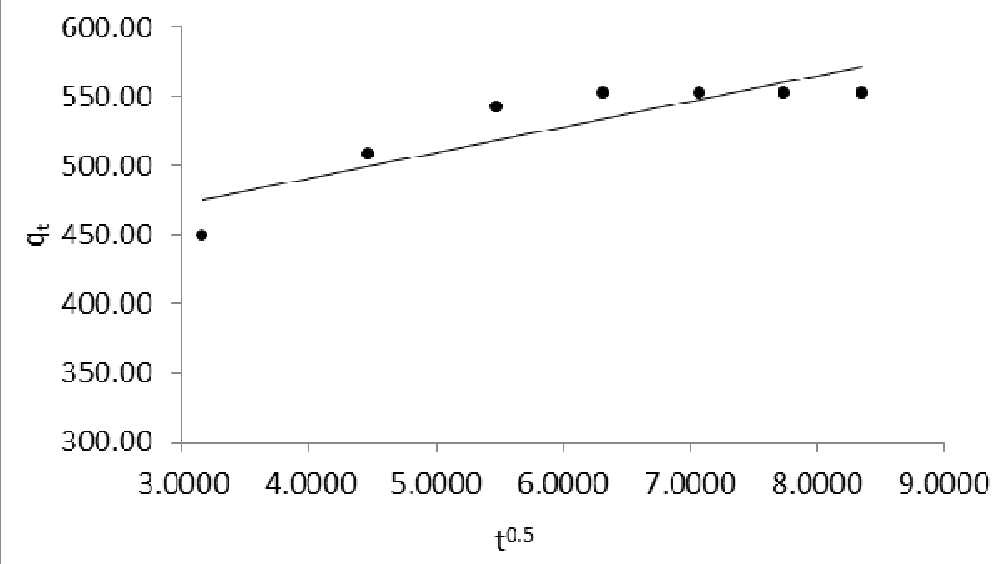

Fig.1: Intra-particle diffusion model

Table 3: Kinetic model parameters for the removal of colour by MSEAC

\begin{tabular}{|c|c|c|}
\hline Kinetic model & Rate constants & Goodness of fit $\left(R^{2}\right)$ \\
\hline Pseudo-first order model & $\begin{array}{l}\mathrm{K}_{1}=0.002993\left[\mathrm{~min}^{-1}\right] \\
\mathrm{q}_{\mathrm{e}}=138.36\left[\mathrm{Pt}-\mathrm{Co} \mathrm{g}^{-1}\right]\end{array}$ & 0.818 \\
\hline Pseudo-second order model & $\begin{array}{l}\mathrm{K}_{2}=0.00025\left[\mathrm{~g} \mathrm{Pt}^{-\mathrm{Co}^{-1}} \mathrm{~min}^{-1}\right] \\
\mathrm{q}_{\mathrm{e}}=1000\left[\mathrm{Pt}-\mathrm{Co} \mathrm{g}^{-1}\right] \\
\mathrm{h}=250\left[\mathrm{Pt}-\mathrm{Co} \mathrm{g}^{-1} \mathrm{~min}^{-1}\right]\end{array}$ & 0.999 \\
\hline Intra-particle diffusion model & $\begin{array}{l}\mathrm{K}_{\mathrm{d}}=18.55\left[\mathrm{~min}^{-1}\right] \\
\mathrm{I}=417\end{array}$ & 0.764 \\
\hline Elovich model & $\begin{array}{l}\beta=0.0187\left[\mathrm{~g} \mathrm{Pt}^{-\mathrm{CO}^{-1}}\right] \\
\alpha=31844.2\left[\mathrm{Pt}-\mathrm{Co} \mathrm{g}^{-1} \mathrm{~min}^{-1}\right]\end{array}$ & 0.871 \\
\hline
\end{tabular}

\section{Results of Chi-Squared Test:}

The results of Chi-squared test on the various isotherm and kinetic models are presented in Table 4. Langmuir isotherm had the least calculated chi- squared $\left(\mathrm{X}^{2}\right.$ cal $)$ value of 5.2 among the isotherms studied, implying it's the best model because it fits the experimental data better than the other models. The Pseudo-second order model emerge the best kinetic model with $X^{2}$ Cal value of 3.2. Results of the chi-squared test is in line with the $R^{2}$ values observed in Tables 2 and 3 .

Table 4: Chi-squared test

\begin{tabular}{|c|c|c|c|}
\hline & \\
\hline Model & $x^{2}$ Cal & $X^{2}$ Tab & Remarks \\
\hline Temkin isotherm & 12.7 & 12.6 & $\begin{array}{l}X^{2}{ }_{\text {Cal }}>X^{2} \text { Tab, hence, model not reliable for } \\
\text { prediction }\end{array}$ \\
\hline Langmuir isotherm & 5.2 & 12.6 & $\begin{array}{l}\mathbf{X}_{\text {cal }}^{2}<\mathbf{X}^{2} \text { Tab, hence, model reliable for } \\
\text { prediction }\end{array}$ \\
\hline Freudlich isotherm & 60952.4 & 12.6 & $\begin{array}{l}\mathrm{X}^{2}{ }_{\text {cal }} \gg \mathrm{X}^{2} \text { Tab, hence, model not reliable for } \\
\text { prediction }\end{array}$ \\
\hline Pseudo-first order model & 4.7 & 12.6 & $\begin{array}{l}\mathbf{X}^{2}{ }_{\text {Cal }}<\mathbf{X}^{2} \text { Tab, hence, model reliable for } \\
\text { prediction }\end{array}$ \\
\hline Pseudo-second order model & 3.2 & 12.6 & $\begin{array}{l}\mathbf{X}^{2}{ }_{\text {cal }}<\mathbf{X}^{2} \text { Tab, hence, model reliable for } \\
\text { prediction }\end{array}$ \\
\hline Intra-particle diffusion model & 6674.8 & 12.6 & $\begin{array}{l}\mathbf{X}_{\text {Cal }}^{2}>\mathbf{X}^{2} \text { Tab, hence, model not reliable for } \\
\text { prediction }\end{array}$ \\
\hline Elovich model & 149.9 & 12.6 & $\begin{array}{l}\mathbf{X}^{2}{ }_{\text {cal }}>\mathbf{X}^{2} \text { Tab, hence, model not reliable for } \\
\text { prediction }\end{array}$ \\
\hline
\end{tabular}




\section{CONCLUSION}

Activated carbons were produced from a local variety of mango seed by carbonizing the endocarp before activation with $\mathrm{ZnCl}_{2}$ using an impregnation ratio of 1:4. Laboratory batch studies were conducted in other to generate data for kinetic and equilibrium modelling of the adsorption of colour by the produced MSEAC in other to determine the mechanism and rate controlling steps of the process. The equilibrium models used included; Langmuir isotherm, Freundlich isotherm and Tempkin isotherm. While the kinetic models used were; first order kinetic, second order kinetic, Intra-particle diffusion, and Elovich models.

The pseudo-second order model gave the highest goodness of fit $\left(R^{2}\right)$ of 0.999 compared to the other kinetic models tested. This implies that chemisorption is the rate controlling step. Langmuir isotherm fit experimental data with high value of goodness of fit $\left(R^{2}\right)$ of 0.998 compared to the other tested isotherm models, which implies that the adsorption process is based on a monolayer adsorption. Chi-squared tests performed on all the models confirm the reliability of the Langmuir and pseudo-second order models over the other isotherm and kinetic models respectively. The results indicate that activated carbon prepared from mango seed endocarp is suitable as adsorbent material for adsorption of colour from textile wastewater. The Langmuir and pseudosecond order kinetic models considered in this study should be used as reliable tools for predicting the adsorption of colour from textile wastewater by the produced MSEAC. Column studies on the produced MSEAC should be carried out to determine the suitability of the MSEAC in column reactors.

\section{REFERENCES}

Aloko, D. F. and Adebayo, G. A., 2007. Production and characterisation of activated carbon from agricultural wastes (rice-husk and corn-cob). J. Engg. Appl. Sci., 2(2): 440-444.

Akpen, G. D., Nwaogazie, I. L. and Leton, T. G., 2011. Optimum conditions for the removal of colour from wastewater by mango seed shell based activated carbon. Indian J. Sci. and Tech., 4(8): 890-894.

Akpen, G. D., Nwaogazie, I. L. and Leton, T. G., 2014. Adsorption characteristics of mango (magnifera indica) seed shell activated carbon for removing phenol from wastewater." J. Appl. Sci.Tech. 19(1\&2): 43-48.

Akpen, G. D., Aho, I. M. and Mamwan, M. H., 2017. Removal of colour from textile wastewater by mango seed endocarp activated carbon. Intern. J. Sci. and Tech., 6: 756-762.

Bello, O. S., Adelaide, O. M., Hammed, M. A. and Popoola, O. A. M., 2010. Kinetic and equilibrium studies of methylene blue removal from aqueous solution by adsorption on treated sawdust,
Macedonian J. Chem. and Chem. Engg., 29(1): 77-85.

Chien, S. H. and Clayton, W. R., 1998. Application of Elovich equation to the kinetics of phosphates release and sorption in soils, In Y. S. Ho, and G. Mckay, A comparison of chemisorption kinetic models applied to pollutant removal on various sorbents, Trans IChem E, 76: 332-340.

Elizalde-Gonalez, M. P. and Hernandez-Montoya, V., 2007. Characterization of mango pit as raw material in the preparation of activated carbon for wastewater treatment, Biochem. Eng. J., 36: 230-238.

Freundlich, H. M. F., 1906. U" ber die adsorption in Io"sungen, Z. Phys. Chem. 57: 385-470.

Gurses, A., Dogar, C., Karaca, S., Acikyildiz, M. and

Bayrak, B., 2006. Production of granular activated carbon from waste rosa canina sp. seeds and its adsorption characteristics for dye, J. Hazard. Mater., 131: 234-259.

Ho, Y. S. and McKay, G. 1998. A comparison of chemisorption kinetic models applied to pollutant removal on various sorbents, Trans IChemE, 76: 332-340.

Ho, Y. S. and McKay, G., 1999. Pseudo-second order model for sorption processes. Process Biochem., 34: 451-465.

Ho, Y. S., Chiu, W. T. and Wang, C. C., 2000. Regression analysis for the sorption isotherms of basic dyes on sugarcane dust, Biores. Tech., 96: 1285-1291.

Kwaghger, A. and Adejoh, E., 2012. Optimization of conditions for the preparation of activated carbon from mango nuts using $\mathrm{ZnCl}_{2}$. Intern. J. Engg. Res. Dev., 1(8): 1-7.

Lagergren, S., 1898. About the theory of so-called adsorption of soluble substances." K. Sven. Vetenskapsakad. Handl, 24(4): 1-39.

Langmuir, I., 1918. The adsorption of gases on plane surfaces of glass, mica and platinum. Amer. Chem. Soc., 40(2): 1361-1403.

Namasivayam, C. and Kavitha, D., 2002. Removal of congo red from water by adsorption onto activated carbon prepared from coir pith, an agricultural solid waste, Dyes Pigments, 54: 4758.

Namasivayam, C., Sangeetha, D. and Gunasekaran, R., 2007. Removal of anions, heavy metals, organics and dyes from water by adsorption onto a new activated carbon from jatropha husk, an agroindustrial solid waste. Trans. IChemE, Part B, Process, Safety and Environ. Prot., 85(B2): 181-184. 
Ochonogor, A. E., Agunwamba, J. C. and Egbuniwe, N.,

1999. Removal of phosphate using activated carbon Terminalia catappa, NJEM, 1(4): 5-15.

Sivakumar, P. and Palanisamy, P. N., 2009. Adsorption studies of basic red 29 by a non-conventional activated carbon prepared from Euphorbia Antiquorum L, Intern. J. ChemTech Res., 1: 502-510.

Temkin, M. I. and Pyzhev, V., 1940. Kinetics of ammonia synthesis on promoted iron catalyst, Acta Physiochim., 12: 327-356.

Valix, M., Cheung, W. H. and McKay, G., 2004. Preparation of activated carbon using low temperature carbonization and physical activation of high ash raw bagasse for acid dye adsorption, Chemosphere, 56: 493-501.

Weber Jr., W. J. and Morris, J. C., 1963. Kinetics of adsorption on carbon from solution. J. Sanit. Engng. Divn, Amer. Soc. Civ. Engrs, 89(2): 3159. 